GÁbrity Molnár IrÉn PhD

gmolnariren@gmail.com

egyetemi rendes tanár (Újvidéki Egyetem,

Közgazdasági Kar Szabadka)

\section{Eredményesség mérése a felsőoktatásban}

\author{
- Measuring of Efficiency \\ in the Higher Education -
}

DOI 10.14232/belv.2016.4.10

https://doi.org/10.14232/belv.2016.4.10

Cikkre való hivatkozás / How to cite this article: Gábrity Molnár Irén (2016): Eredményesség mérése a felsőoktatásban. Belvedere Meridionale 28. évf. 4. sz. 134-138. pp

ISSN 1419-0222 (print)

ISSN 2064-5929 (online, pdf)

(Creative Commons) Nevezd meg! - Így add tovább! 4.0 (CC BY-SA 4.0)

(Creative Commons) Attribution-ShareAlike 4.0 International (CC BY-SA 4.0)

www.belvedere-meridionale.hu

1. Pusztai Gabriella - Kovács Klára (szerk.) (2015): Ki eredményes a felsőoktatásban? Felsőoktatás \& Társadalom 1. Nagyvárad-Budapest, 2015, Partium Könyvkiadó, Personal Problems Solution, Új Mandátum Könyvkiadó. 240 pp.

2. Pusztai Gabriella - Bocsi Veronika - CEgLÉdi TímeA (szerk.) (2016): A felsőoktatás (hozzáadott) értéke: Közelitések az intézményi hozzájárulás empirikus megragadásához. Felsőoktatás-Társadalom 6. Nagyvárad-Budapest, 2016, Partium, Personal Problems Solution, Új Mandátum Könyvkiadó. 371 pp.

A debreceni kutatócsoport többéves szak- avatott munkáját mutatja be két tanulmánykötetben, amelynek megjelenését a Debreceni Egyetem Kutatási Pályázata támogatta, a Felsőoktatás \& Társadalom sorozatának a keretében. Egyes tanulmányok az Európai Unió és Magyarország támogatásával, az Európai Szociális Alap társfinanszírozásával a „Nemzeti Kiválóság Program - illetve kutatói személyi támogatást biztosító rendszer kidolgozása és működtetése országos program" című kiemelt projekt keretei között valósultak meg. A kutatócsoport munkájának kiindulópontja egy alapprobléma, mégpedig az, hogy a tömeges felsőoktatás világában még a közoktatásnál is kevéssé tisztázott a hallgatói eredményesség fogalma. Az utóbbi évtizedben, a nagyobb számú beiratkozottakhoz viszonyítva, a diplomások aránya megtorpant, aminek az oka: a többciklusú képzésre való áttérés, a gazdasági válság miatt csökkenő költségvetési és családi erőforrások, a demográfia hullámvölgy, a nemzetközi mobilitás megélénkülésével a külföldi intézmények vonzereje, a nyelvi követelmények.

A két könyv impozáns csapatmunka eredménye, ugyanis az elsőben 22, a másodikban pedig 35 szerző adta be a munkáját. Empirikus kutatásaikat (kérdöívezés, fókuszcsoportos interjúk) még 2014-ben kezdték. Megállapítják, hogy a hallgatói eredményesség többdimenziós mutató, amiben mindenképpen benne vannak az egyénben rejlö lehetőségek kibontakozásához szükséges intézményi környezet, vagyis az intézményi hatásmechanizmusok a különböző hallgatói kompozíciók felé. A Debreceni Egyetem Felsőoktatási Kutató és Fejlesztő Központja által az utóbbi másfél évtizedben végzett kutatásokkal felhívták a figyelmet arra, hogy a széles körben elfogadott, univerzális felsőoktatási eredményességi indikátorok nem elegendők, újakat kell felvezetni. Ez kritikus szembenézés az oktatáskutatásban levő eredményesség-felfogásokkal szemben. A tanulmánykötetben a szerzők elsősorban a hallgatók felsőoktatási eredményességének 
megközelítési lehetőségeivel, az eredményességet támogató intézményi és intézményen kívüli tényezőkkel foglalkoznak. Itt van néhány speciális hallgatói csoport sikeres karrier befutásának mérlegelése is.

Az oktatásban ismert az a tény, hogy már az előnyt jelent egy intézménynek, ha a legfelkészültebb tanulókat csalogatják magukhoz, mert befektetés nélkül még jobb eredményt érnek el. Debrecen és vonzáskörzete egyik legfontosabb kihívása, az alacsony társadalmi státusú hallgatók egyetemi boldogulása. A következő kérdés pedig adódik: milyen mér tékben formálható a belépő hallgatók magával hozott tudása, képessége? Nem csak az a fontos, hogy egy egyetem milyen hallgatói bemenettel és kimenettel rendelkezik, hanem mérjük meg már a hallgatói előrelépés elemeit magukon a karokon. Nem elég tehát elemezni a diplomázás utáni elhelyezkedési lehetőségek és a felvételin hozott pontok közötti eltérést. Pusztai Gabriella kutatásai szerint ,jelentős egyenlőtlenségek létezését tudtuk igazolni, melyek a családi státus reprodukálódását jelzik előre annak ellenére, hogy e korcsoport elött hazai viszonylatban eddig példa nélküli lehetőségek nyíltak meg a felsőoktatás bővülésével." (PuszTAI 2015: 94.) Éppen ezért a kapcsolati erőtér néven összefoglalt tényezőcsoport a családi státusmutatók mellett igen fontos! Az eredményességnek a mérésére szolgál a felsőoktatási hozzáadott érték, amelynek pontos meghatározása azért is nehézkes, mert számos tényező befolyásolja azt, hogy a hallgató a felsőoktatási intézményben töltött évek során milyen mértékben fejlődik (kor, nem, lakóhely, társadalmi háttér, meglévő képességek és készségek szintje, személyiség jellemzők, az intézményi oktatás, a szolgáltatások jellege és minősége, valamint azok elérhetősége). (Bocsi 2015: 141.) A sokoldalú megközelítési lehetőségek miatt a hozzáadott érték mérésénél mindig pontosan kell definiálni azt, hogy milyen képességeket vagy teljesítményt tesztelünk. Állítom, hogy egy kedvezőtlen oktatáspolitikai háttér és a felsőoktatás helyzetének bizonytalansága az intézmények hatásrendszerét csak kevéssé befolyásolja, inkább az intézmények légkörére, oktatási színvonalára, belső világára gyakorol kedvezőtlen hatást.

A szerzők kutatócsoportja a hallgatói eredményesség megbízható mutatóit keresve több kísérletet tett a felsőoktatás viszonyrendszerén belüli tényezők azonosítására. Megvizsgálták az egyes felsőoktatási szinteken tapasztalt személyes karrierterveket, a tanulmányi munkát és azon kívüli extra tevékenységeket, a vizsga effektivitás viszonyított mértékét, az akadémiai normáknak megfelelő hallgatói munkavégzést, sőt a munkába állás tervezése terén mutatkozó hallgatói különbségeket is. Górcső alá került a hallgatók intézményi menedzselése is. A leendő és a pályakezdő tanárok esetében, sajnos jelentős részük bizonytalan a jövőt illetően, sőt kétharmadnál is nagyobb azok aránya, akik már az első években fontolgatják a pályaelhagyást. A hallgatók tanári pálya iránti hosszú távú elkötelezettségét a presztízsről alkotott véleményük mellett jelentősen befolyásolja az autonómia, érdekérvényesítés, megbecsültség, érvényesülési lehetőségek megítélése is (Kovács 2015. 183.). Amikor a gyakorlatban összehasonlították az orvosokat a pedagógusoknál kedvezőbb családi háttér, erősebb középfokú és felsőfokú képzés jellemzi (IMRE 2015. 229.). A tanárokkal, akkor az elöbbieket hosszabb és lineárisabb tanulmányi út, s jobb munkaerő-piaci helyzet jellemzi. A tanulmányok hasznosíthatósága a tanárok esetében kifejezetten kedvezőtlen, s vélhetőleg a rossz munkaerö-piaci feltételek mellett ez is hozzájárul a pályaelhagyáshoz.

A kötet szerzői figyelemmel kísérték a felsőoktatási kompetenciamérések tapasztalatait, a rendelkezésükre álló adatokra támaszkodva maguk is elvégezték az elemzéseket. Miközben a szakértők a felsőoktatás akadémiai teljesítményét helyezik előtérbe, a megoldásokat intézményi, döntéshozói és finanszírozási oldalról közelítik meg, ugyanakkor a felső- 
oktatás nevelő funkciója döntő lehet. Lásd Ceglédi Tímea kéziratában (2015. 9-24.) a szakkollégiumok oktatói munkát, a közösségi létet; Dusa Ágnes Réka (2015. 25-41.) írását a nemzetközi mobilitásról; KIss Zsuzsanna írását a fiatalok álláskereséséről (2015. 55-65.). A következtetés, amihez a debreceni kutatók jutottak, mindenképpen azt tanúsítja, hogy a felsőoktatási eredményesség kutatói eddig nem igen voltak sikeresek, de hozzájárultak ahhoz az aktív diskurzushoz, amely a sikerkoncepciókról szól.

Újra bizonyított az a megállapítás, hogy egy felsőoktatási intézmény rendkívül hatásosan képes formálni egy-egy társég fejleszthetőségét, vagyis emberi tényezőjének minőségét. Kiderül, hogy a budapesti felsőoktatás elszívó hatása nemcsak a felsőoktatási tanulmányokra korlátozódik, mivel a végzősök munkahelye tekintetében is dominál (HEGEDÜs 2015. 97-107.). Ne csodálkozzunk azon, hogy a vidéki városi intézmények aktuális fejlesztési stratégiái a tudományegyetemmé való átalakulás vagy a közösségi föiskolai típus irányába mutatnak, nem pedig a sorvadás felé.

A kutatócsoport második tanulmánykötetében (2016.) az alaptéma továbbfejlesztett és jóval alaposabb körültekintéssel vették sorba a releváns tényezőket. A felsőoktatási intézményi hatás összetett jelenség, melynek kutatásához komplex látásmód és türelem szükséges. Az intézményi hatás nem merül ki a kiadott diplomák számában, minősítésében, sőt még a szakterületen illetékes tudásanyagban sem, mivel akkor is realizálódik, amikor látszólag minimális beavatkozással üzemel egy rendszer. Ha a felsőoktatás aktív szereplői nem ismerik fel az egyetemi években rejlö lehetőségeket, akkor a hallgatói szocializáció kimarad, vagy intézményi kontroll nélkül zajlik. Ilyen esetekben elpazarlódnak a beinvesztált költségek, s a kampuszon töltött évek hatása minimalizálódik.

Változások tudatában a szerzők megállapítják, hogy a felsőoktatás tömegessé válása alapvetően átszabta az intézmények működését. Megváltozott a hallgatók társadalmi és kulturális összetétele, de átalakult a felsőoktatásban dolgozó oktatók és kutatók világa is. Megváltozott a külső környezet is: a munkaerőpiac átalakult, a fiataloktól elvárt készségek újak. Éppen ennek hatására a tanítási metódusok és a tananyag is átstrukturálódott. A szerzők, a vizsgált régió két évtizeddel korábbi adataival összevetve elmondják, hogy az intézmények működésének létmódja is gyökeresen átalakult. Az egyetemek által vállalt és a ténylegesen megvalósuló funkciók jelentősen kibővültek, s a felsőoktatás sokszínűvé vált (PuszTAI - Bocsi - Ceglédi 2016. 7-12.). Mivel az intézményrendszer folyamatosan is diverzifikálódik, a felsőoktatási intézmények hatásai sem egyformán alakulnak. A kötetben a szerzők jelentős előrelépést mutatnak ama tény bizonyításában, hogy a hallgatói eredményesség ugyan megjósolható a család társadalmi-gazdasági státusa és a korábbi teljesítménymutatók (belépéskori pontszámok, ennek a középiskolai teljesítményt összegző komponense) alapján, de! Ez a megközelítés nem tartja jelentősnek a hallgatói tudás, képességek, értékrend formálódásához való intézményi hozzájárulást. Kutatásukban a felsőoktatási intézményekre úgy tekintettek, amelyekben speciális transzformációs folyamatok zajlanak a hallgatói belépéshez (inputhoz) képest.

A debreceni kutatás izgalmas volt, ugyanis az intézményi hatásgyakorlás nem kifejezetten a tervezett folyamatok szerint ment végbe. A projekt első szakaszában megfelelő eredményességi mutatók azonosításával foglalkoztak, azzal, hogy egyéni szinten az eredményességi dimenziók hogyan viszonyulnak egymáshoz, vagy, hogy az eredményesség több dimenziója milyen komplex módon alkalmazható együttesen. Pedig, a hatások, amelyek a diákokat érik, nehezen azonosíthatók. A kutatás második szakaszában azt a kérdést gondolták tovább, hogy milyen felismert tényezők magyarázzák az eredményesség egyéni illetve intézményi 
különbségeit. A kérdés: milyen intézményi környezet esetében tapasztalhatjuk a legintenzívebb változásokat a hallgatók gondolkodásában, kompetenciáiban és magatartásában? A kötetben a igyekszenek kiszürni a fiatalokat érintő változásokból az intézményi hatások elemeit. A cél tehát nem csupán a változásoknak és hatásmechanizmusoknak a feltárása, hanem megmagyarázni/ modellezni a hallgatói képesség alakulását.

A 2016-ban publikált tanulmányok négy témakör köré rendeződnek. Az első, az intézményi hatás komparatív szemszögből (Bocsi - CEgLÉDi 2016. 13-32.), a nemzetközi kutatási tapasztalatokkal együtt (Roger 2016. 33-54.). Ezután a Komplex megközelítések, módszertani kihívások címü fejezetben két, egymásnak ellentmondó kihívásnak próbálnak megfelelni a szerzők. Az egyik kihívás az intézményi hatás komplexitásának megragadása, a másik pedig a mérés érvényessége és megközelítő pontossága; miközben nyitottak az új módszertani kísérletekre is. Napirendre kerül a hozzáadott érték mérése (RodGERs 2016. 90-111.), az intézményi hatás forrásai (Pusztai 2016. 112-136.), és az intézményi hatás elemzése a kereseti különbségekben (Kun 2016. 165-176.). A harmadik, Hallgatói nézőpontok címü fejezetben a hallgatók fejlődését mutatják be: hogyan formálódik szakmai identitásuk (KoLTói 2016. 211-220.), milyenek a marginálizált helyzetü társaikkal szembeni attitüdjeik (BEREI 2016. 290-301), hogyan állunk az IKT-eszközök használatával (LABANCZ - BARNUNCZ 2016. 262-277.), az önkéntességgel (FÉNYES - MARKos 2016. 248-261.), a vallás és egészség kapcsolatával (Hodossi - MÁrkus 2016. 278289.), vagy a nyelvtudással (SEBESTYÉN 2016. 234-247.). Mi a véleményük a munka vagy a család mellett tanulóknak, vagyis a levelezős hallgatóknak? (ENGLER 2016. 221-232.). Az utolsó, Intézményi nézőpontok témakörben a szerzők a szakkollégium intézményi hatását elemzik: CEGLÉDI et al. (2016. 302-316.), azután JANCSÁK (2016. 328-337.); JENEI-KERÜ-
LÖ (2016. 317-326.). Fekete (2016. 351-360.) a kommunikatív kompetenciát fejtegeti, Kováts et al. (2016. 338-350.) pedig a kritikai üzleti szemléletformálás témával foglalkoznak.

A szerzők a felsőoktatási hatáselemzések során felismerték, hogy e jelenség nem vizsgálható anélkül, hogy fel ne ismernénk az intézmények hallgatói és oktatói kompozícióinak, a regionális és lokális, a szervezeti, oktatási és nevelési feladatoknak, valamint az intézményi kultúráknak a végtelen sokféleségét. A tanulmánykötet jelentős számú empirikus kutatás után közli a tanulságokat, amiben különösen Kozma, Pusztai, Juhász, Ceglédi, Engler, Morvar jeleskednek. A hallgatók életfelfogását, készségeit, kompetenciáit és gondolkodását az egyetemek világának komplex hatásmechanizmusa formálja. A változás mértékéért ugyanakkor a hallgató is felelős, mivel aktív szereplöje a folyamatnak. Az egyetemista és az karok találkozásának mélysége számos tényezőtől függ. Kiemelkedő fontossággal bírnak a kari sajátosságok és a családi háttér komponensei, a motivációknak az egyéni alakzatai is. A narratívák alapján elmondhatjuk, hogy a hallgatók érzelmi szálon közelítenek az általunk felvetett témákhoz és a kampusz világához: egyértelmüen az élményeiken keresztül élik meg az egyetemet. Felnőttként tekintenek magukra, az első lépéseket sok szempontból mégis az egyetemtől várják.

A hallgatói szocializáció folyamatának felfelé ívelő szakasza nem rögtön a beiratkozással kezdődik: a tényezők sorában, amelyek hatnak a hallgatókra, elsősorban az emberi kapcsolatok fontosak (a hallgatótársak és az oktatók). Az emberközeliség igénye hatalmas. A diákok sok esetben személytelennek látják az intézményi kereteket, ami nem csak a magasabb hallgatói létszám következménye. Nem kétséges, hogy ha az intézmények a személyiség- és készségformálás hatásmechanizmusát szeretnék javítani, a személyes kapcsolathálókra érdemes támaszkodni. A lezajlott változások területeinek sorában a hallgatók elsődlegesen 
a személyiségük alakulása emelhető ki, s ebbe van benne szakmai fejlődésük. Ezeket a változásokat nem csak az egyetemnek tulajdonítják, hanem az életkorral járó és az egyéb közösségeikben megjelenő (család, barátok) hatásokat is érzékelik. A Spellings-bizottság (U.S. Department of Education, 2006) által a legmegbízhatóbbnak nevezett erre irányuló mérőeszköz a CLA, a felsőoktatás eredményességét jelző kompetenciák és képességek közül a kritikus gondolkodást, az elemző érvelést, a problémamegoldó képességet és az írásbeli kommunikációs képességet vizsgálja, amit a hétköznapi életből származó élethelyzetekre épülő feladatok alkalmazásával méri és értel- mezi. Ugyanakkor az elemzési egység mégsem a hallgató, hanem az intézmény és így rangsorok kialakítására is lehetőség nyílik. A CLA 1, a megfelelő módosítások és kiegészítések végrehajtásával alkalmassá válhat arra, hogy a felsőoktatási hozzáadott érték meghatározásában nemzetközi mérőeszközzé váljon.

A két kötet hasznos minden olyan szakember részére, aki a felsőoktatási intézmények hatásmechanizmusát kutatja, vagy fejlesztené. A szerzők a tanulmánykötetet mindazoknak ajánlják, akik résztvevői, „fogyasztói”, működtetői, alakítói, finanszírozói, nyertesei, kiszolgálói, kiszolgáltatottjai, szemlélői, tisztelői, kritikusai a felsőoktatási intézmények mindennapjainak. 